第 49 巻第 3 号岩石鉱物鉱床学会誌 1963 年 3 月 5 日

研 究 報 文

\title{
CHEMICAL COMPOSITION OF PALEOZOIC ROCKS FROM NORTHERN KISO DISTRICT AND OF TOYOMA CLAYSSLATES IN KITAKAMI MOUNTAINLAND: \\ I. CHEMICAL COMPOSITION OF PELITIC ROCKS
}

\author{
Masato Katada, Hiroshi Isomi, Ei Ōmori aNd \\ TEIKo YAMADA \\ Geological Survey of Japan, Kareasaki
}

\section{INTRODUCTION}

Katada and Isomi have engaged in the geological research in the northern part of the Kiso mountainland for several years and have published seven reports on the geology. In this paper the present authors intend to publish the chemical composition of Paleozoic pelitic rocks (clayslates) and their metamorphosed derivatives from this district and to make brief remarks on their geological significance. Seventeen analyses are accomplished by Omori and Yamada. In connection with this study, two clayslates of the Toyoma formation from Kamiarisu-mura in the Kitakami mountainland are also analysed (Fig. 1). Besides the major elements reported in this paper, determination of contents of $\mathrm{CO}_{2}$ and $\mathrm{C}$ are now carried on and their results will be reported in

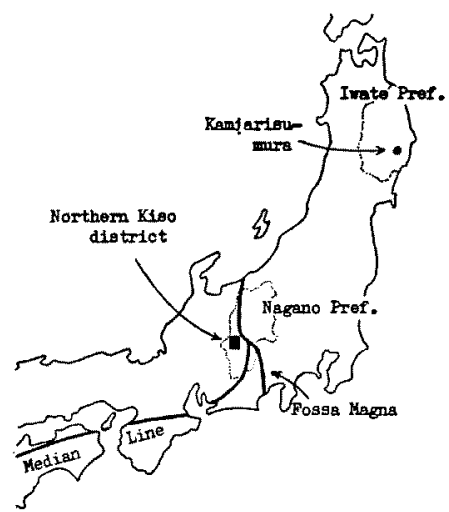

Fig. 1. Location of northern Kiso district and Kamiarisu-mura.

(Manuscript received, September 13, 1962) 
the next report which deals with the chemical composition of sandstones and basalts.

Chemical data on Paleozoic rocks in Japan are rather rare. But such is not the case for the clayslates from the northern Kiso district, for fifteen chemical analyses by Haramura (1961) and six by Oki (1961) were recently published. Therefore, the two author's results have been refered in our study. The total number of chemical analyses of Paleozoic clayslates from this district, inclusive of those by other authors, amounts to nearly forty.

The authors owe their deepest gratitude to Dr. A. Miyashiro and Mr. H. Haramura of Tokyo University who generously showed us their unpublished data.

\section{Lithological and Petrological Outline of Paleozoic Sediments in Northern Kiso District}

The Permian in the northern Kiso district forms a thick pile of geosynclinal sediments, consisting mainly of clayslate, graywacke and chert. A small amount of basalt, limestone and conglomerate are also intercalated.

The Paleozoic terrain is divided into five lithofacies zones parallel to each other. Every zone has its own over-all lithological characteristics and is discriminated from each other, and further, runs in parallel to the general structural trend of this region (Fig. 2). Therefore, they are classified as follows:

Yabuhara formation is characterized by abundance of chert and/or cherty mudstone, comparatively rich in basalt and lenticles of limestone, and poor in ferrigenous matter. This formation is the oldest of the five formations and forms an axial part of the anticlinorium.

Misogawa formation consists mainly of massive coarse-grained sandstone, clayslate and their alternation of variable thickness. Poor in chert. This formation rests conformably upon the Yabuhara formation on the northwestern side of the anticlinorium.

Narai formation is composed mainly of clayslate. Poor in massive coarse-grained sandstone and chert. This formation covers conformably the Yabuhara formation on the southeastern side of the anticlinorium. Accordingly, it is almost synchronous with the Misogawa formation but its lithofacies is distinctly different from the latter.

Yokokawa formation is characterized by abundance in bedded chert, interbedded with clayslate, and relatively poor in sandstone. 
This formation covers conformably the Narai formation and is distributed exclusively on the southeastern side of the latter.

Kuwazawa formation is characterized by abundance of massive coarse-grained sandstone which is frequently accompanied by a sort of intraformational conglomerate. This formation is the

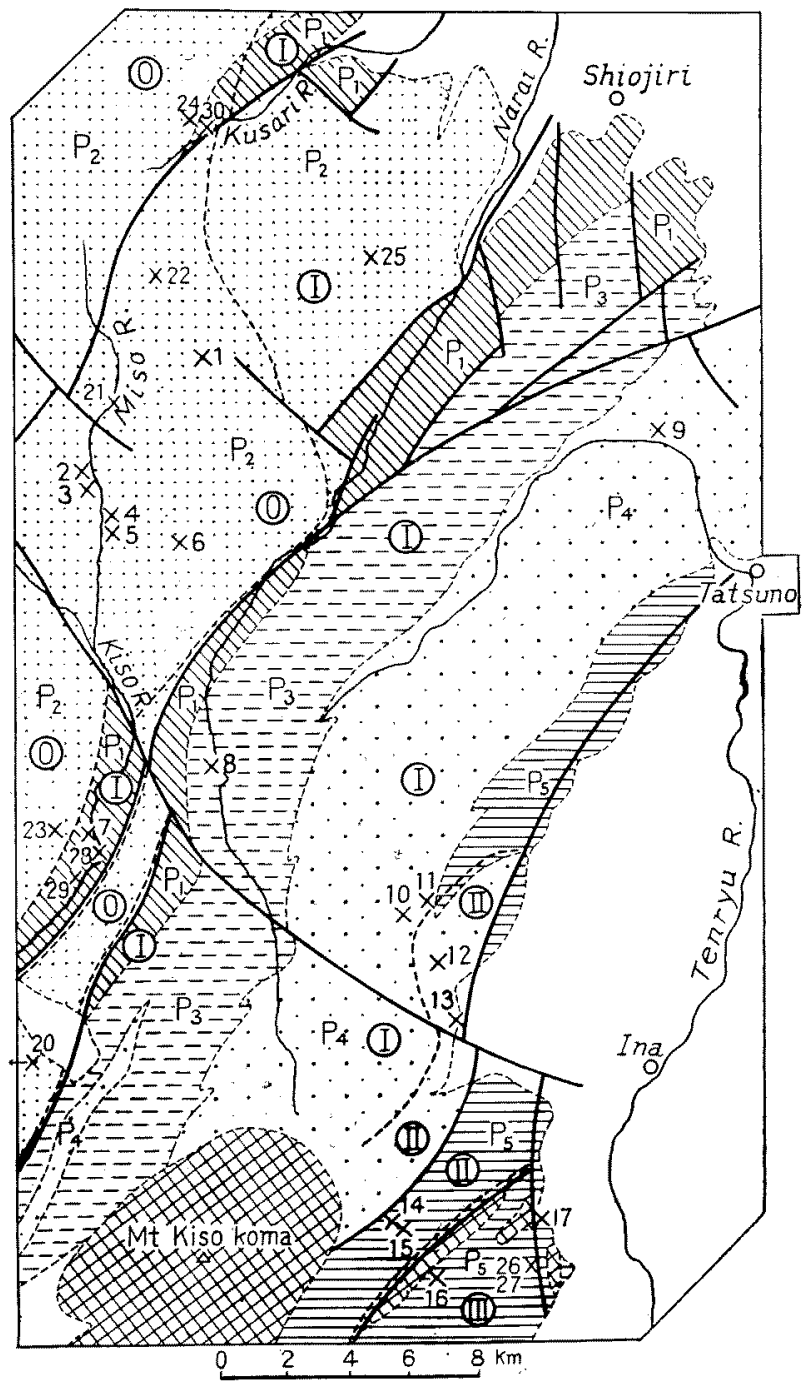

Fig. 2. Geologic sketch map of northern Kiso district. 


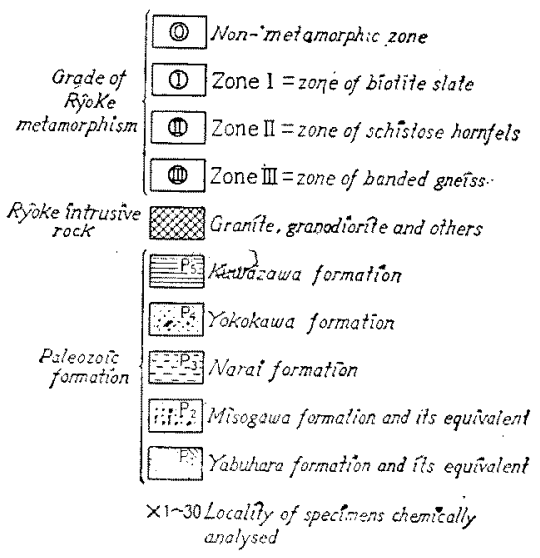

youngest of all, and occurs in the axial part of the synclinorium in the southeastern part of the region.

Except the lowermost Yabuhara formation, the Paleozoic formations show the "flysch-like" lithofacies; i.e. 1) texture of sandsonte shows graywackish nature; 2) most of massive coarse-grained sandstone contains clayslate rubble of syn-sedimentation origin; 3) some of massive coarse-grained sandstone layers accompany breccia rock or conglomerate consisting of non-rounded rock fragments; 4) thin layer or mere lamina concentrated with carbonized plant fragments is intercalated within siltstone or fine-grained sandstone; 5) Heliminthoides, a fossil trail characteristic in the flysch type of sediments, is frequently found between clayslate and siltstone or fine-grained sandsonte; 6) except rare fusulinid fossils in limestone, megafossils are not yielded at all.

Lithological characteristics of orthogeosyncline are also recognized as well. Namely, 1) chert develops within the formations which bear some remarkable characteristics of flysch-like sediments, and the chert interfingers with ferrigenous sediment; 2) basalt pyroclastics and lava (so-called schalstein) form not only the main constitutent of the Yabuhara formation but also thin intercalations or lenticles within th other formations.

Consequently, the Paleozoic rocks are intermediate between flysch-like and orthogeosynclinal sediments. It is remarkable that

Nos. $20 \sim 30$ is the localities of psammitic rocks and basalts which will be reported in the next paper. 
lithological elements of miogeosyncline and eugeosyncline are intricately mixed with each other within the Paleozoics under discussion.

Yabuhara formation yields Yabeina, so its geological age is early Late Permian. Though the other formations which occupy higher position in the column are all barren of index fossils, they are safely concluded to belong to Upper Permian. It is noteworthy that these formations exclusively of Upper Permian attain to the large thickness of sveral thousands of meters, indicating that the rate of sedimentation was unusually rapid.

Paleozoic rocks are more or less regionally metamorphosed by the Ryôke metamorphism, except the northwestern area where the rocks are not metamorphosed. The grade of metamorphism progressively rises toward southwest. Throughout both nonmetamorphic and metamorphic terrains, the lithofacies and the geologic structures are essentially identical, and the zonal arrangement of formations persists even in the metamorphic terrain. No tectonic line or major fault exists between the two terrains.

The metamorphic rocks are divided progressively into three metamorphic zones.

Zone $I=$ zone of biotite slate: the characteristic constiutents are biotite, actinolite, and dolomite. Megascopically, the rocks do not show any schistose or phyllitic appearance. Microscopically, metamorphic minerals are merely sporadically found.

Zone $I I=$ zone of schistose hornfels: The rocks carry andalusite, blue-green hornblende, clinopyroxene and garnets, etc. The rocks are over-all recrystallized. Their original clastic structure, however, still remains.

Zone $I I I=$ zone of banded gneiss: characteristic mineral constitutents are sillimanite and wollastonite. The rocks show coarser banded structure.

The Ryôke metamorphism is considered to have occurred under considerably static condition without strong disturbance and lower hydrostatic pressure.

\section{Clayslates (Mudstones AND Siltstones) from \\ NORTHERN KISO DISTRICT}

Clayslate should be divided into mudstone and siltstone according to their grain-size grade. As their macroscopic distinction is frequently difficult, they were treated as a single kind of pelitic 
Table 1. Chemical composition

\begin{tabular}{|c|c|c|c|c|c|c|c|c|}
\hline Sample no. & 1 & 2 & 3 & 4 & 5 & 6 & 7 & 8 \\
\hline $\begin{array}{l}\mathrm{SiO}_{2} \\
\mathrm{TiO}_{2} \\
\mathrm{Al}_{2} \mathrm{O}_{3} \\
\mathrm{Fe}_{2} \mathrm{O}_{3} \\
\mathrm{FeO} \\
\mathrm{MnO} \\
\mathrm{MgO} \\
\mathrm{CaO} \\
\mathrm{Na}_{2} \mathrm{O} \\
\mathrm{K}_{2} \mathrm{O} \\
\mathrm{P}_{2} \mathrm{O}_{5} \\
\mathrm{H}_{2} \mathrm{O}+ \\
\mathrm{H}_{2} \mathrm{O}-\end{array}$ & $\begin{array}{r}59.50 \\
0.78 \\
18.49 \\
3.62 \\
2.35 \\
0.02 \\
2.18 \\
0.26 \\
1.69 \\
4.31 \\
0.24 \\
4.10 \\
0.82\end{array}$ & $\begin{array}{r}62.77 \\
0.78 \\
16.60 \\
2.71 \\
2.74 \\
0.18 \\
2.06 \\
0.50 \\
1.84 \\
3.60 \\
0.25 \\
3.57 \\
1.30\end{array}$ & $\begin{array}{r}64.92 \\
0.73 \\
15.87 \\
2.80 \\
1.73 \\
0.05 \\
1.96 \\
0.36 \\
1.94 \\
3.64 \\
0.21 \\
3.53 \\
1.05\end{array}$ & $\begin{array}{r}59.22 \\
0.83 \\
18.45 \\
3.46 \\
2.01 \\
0.01 \\
2.20 \\
0.34 \\
1.62 \\
4.42 \\
0.18 \\
4.05 \\
0.93\end{array}$ & $\begin{array}{r}58.06 \\
0.71 \\
18.81 \\
4.12 \\
2.12 \\
0.03 \\
2.25 \\
0.26 \\
1.16 \\
4.54 \\
0.19 \\
4.46 \\
1.30\end{array}$ & $\begin{array}{r}62.60 \\
0.73 \\
15.89 \\
3.85 \\
2.29 \\
0.01 \\
2.22 \\
0.16 \\
1.16 \\
3.51 \\
0.23 \\
3.77 \\
0.93\end{array}$ & $\begin{array}{r}64.34 \\
0.75 \\
17.29 \\
1.64 \\
3.50 \\
0.04 \\
2.30 \\
0.47 \\
1.70 \\
4.76 \\
0.15 \\
2.30 \\
0.32\end{array}$ & $\begin{array}{r}69.70 \\
0.62 \\
14.59 \\
2.40 \\
1.69 \\
0.01 \\
1.51 \\
0.21 \\
3.16 \\
2.60 \\
0.16 \\
2.11 \\
0.32\end{array}$ \\
\hline Total & 99.36 & 98.90 & 98.79 & 97.72 & 98.01 & 97.35 & 99.59 & 99.08 \\
\hline
\end{tabular}

1: a) Mudstone, fine-grained b) Not metamorphosed c) Ikenosawa (池の沢)，Miso-gawa (時噌川)，Kiso-mura (木殂村). Nishichikuma-gun (西筑摩郡), Nagano Pref.

2: a) Mudstone, inlcuding grains of silty size b) Not metamorphosed c) Miso-gawa, Kiso-mura, Nishichikuma-gun

3: a) Mudsonte or siltstone b) Not metamorphosed c) Miso-gawa, Kiso-mura, Nishichilkuma-gun

4: a) Mudstone, including grains of silty size b) Not metamorphosed c) Miso-gawa, Kiso-mura, Nishichikuma-gun

5: a) Mudstone, fine-grained b) Not metamorphosed c) Miso-gawa, Kiso-mura, Nishichikuma-gun

6 a) Mudstone, including grains of silty size b) Not metamorphosed

c) Shiozawa (塩沢), Kiso-mura, Nishichikuma-gun

7: a) Mudstone, slightly cherty b) Zone 1; quartz, feldspar, muscovite, biotite, chlorite and graphite c) Yoshida (吉田), Kiso-mura, Nishichikumagun

8: a) Siltdstone or fine-grained sandstone b) Zone I; quartz, feldspar, muscovite, biotite, graphite and iron-ore c) Okushiomizu (奥塩水), Narakawa-mura (醕川村), Nishichikuma-gun

9: a) Mudstone, very fine-grained b) Zone I; quartz, feldspar, chlorite, muscovite, graphite and iron-ore c) Watado (渡戸), Tatsunomachi (辰野町), Kamiina-gun (上伊那)

10: a) Mudstone, including fine quartz veinlet b) Zone I; quartz, feldspar, muscovite, chlorite and graphite c) Upper stream of Kitazawa (北沢), Ina City (那市), Kamiina-gun

11: a) Mudstone, cherty b) Highest grade part of Zone I; quartz, cordierite, biotite, muscovite and iron-ore c) Upper stream of Kitazawa, Ina City, Kamuna-gun 
of Paleozoic clayslates

\begin{tabular}{|c|c|c|c|c|c|c|c|c|c|c|}
\hline 9 & 10 & 11 & 12 & 13 & 14 & 15 & 16 & 17 & 18 & 19 \\
\hline $\begin{array}{r}56.24 \\
0.98\end{array}$ & $\begin{array}{r}64.44 \\
0.65\end{array}$ & $\begin{array}{r}75.12 \\
0.47\end{array}$ & $\begin{array}{r}67.94 \\
0.58\end{array}$ & $\begin{array}{r}62.69 \\
0.63\end{array}$ & 55.62 & 69.90 & 62.42 & 64.00 & 60.92 & 61.60 \\
\hline 19.75 & 16.73 & 11.21 & $\begin{array}{r}0.58 \\
14.45\end{array}$ & $\begin{array}{r}0.63 \\
17.59\end{array}$ & $\begin{array}{r}0.81 \\
22.13\end{array}$ & $\begin{array}{r}0.54 \\
14.01\end{array}$ & $\begin{array}{r}0.75 \\
17.58\end{array}$ & $\begin{array}{r}0.66 \\
17.57\end{array}$ & $\begin{array}{r}0.80 \\
17.88\end{array}$ & $\begin{array}{r}0.82 \\
17.51\end{array}$ \\
\hline 3.21 & 2.60 & 1.06 & 0.96 & 1.36 & 1.05 & 0.49 & 1.02 & 0.72 & 2.18 & 1.95 \\
\hline 3.8 & 3.04 & 3.46 & 3.90 & 4.72 & 4.33 & 4.04 & 5.24 & 4.17 & 4.51 & 4.53 \\
\hline 0.01 & 0.03 & 0.14 & 0.05 & 0.08 & 0.08 & 0.06 & 0.07 & 0.04 & 0.06 & 0.06 \\
\hline 2.6 & 2.11 & 2.30 & 2.16 & 2.77 & 2.28 & 1.96 & 2.76 & 2.26 & 2.89 & 3.02 \\
\hline 0.10 & 0.72 & 0.34 & 1.67 & 0.94 & 1. 12 & 1.68 & 0.84 & 0.97 & 0.79 & 0.44 \\
\hline 2.5 & 1.92 & 1.2 & 2.59 & 2.06 & 2.35 & 2.56 & 2.15 & 1.73 & 2.95 & 2.95 \\
\hline 3.96 & 3.28 & 2.57 & 3.59 & 4.06 & 6.90 & 2.35 & 4.40 & 5.50 & 2. & 2.32 \\
\hline 0.16 & 0.11 & 0.17 & 0.15 & 0.17 & 0.19 & 0.15 & 0.11 & 0.16 & 0.23 & 0.20 \\
\hline 4.31 & 3.19 & 1.59 & 0.95 & 1.96 & 1.61 & 1.34 & 1.70 & 1.43 & 3.83 & 3.60 \\
\hline 0.46 & 0.46 & 0.10 & 0.18 & 0.28 & 0.10 & 0.06 & 0.12 & 0.20 & 0.29 & 0.44 \\
\hline 98.18 & 99.28 & 99.78 & 99.17 & 31 & 57 & 99.14 & 99.16 & .41 & 9.78 & 9.44 \\
\hline
\end{tabular}

(Analysed by E. Ōmori and T. Yamada)

12: a) Siltstone, including mudstone lamina b) Zone II; quartz, plagioclase, microcline, muscovite, graphite and iron-ore c) Kitazawa, Ina City, Kamiina-gun

13: a) Mudstone b) Zone II; quartz, cordierite, biotite, muscovite, plagioclase, graphite and iron-ore c) Minamisawa, (莘沢), Ina City, Kamiina-gun

11: a) Schistose hornfels of possible very fine-grained mudstone origin b) Zone II; quartz, muscovitized andalusite, plagioclase, microcline, muscovite, biotite, iron-ore and graphite c) Kuro-kawa (黒/11), Otagirigawa (太田切川), Komagane City(駒力根市), Kamiina-gun

15: a) Schistose hornfels of possible siltstone or fine-grained sandstone origin

b) Zone II: quartz, cordierite, biotite, muscovite, plagioclase, microcline and iron-ore c) Kuro-kawa, Otagiri-gawa, Komagane City, Kamiina-gun

16: a) Gneiss of possible mudstone origin b) Zone III; quartz, orthoclase, plagioclase, sillimanite, biotite, muscovite, cordierite (?) and iron-ore c) Kuro-kawa, Otagiri-gawa, Komagane City, Kamiina-gun

17: a) Gneiss of possible siltstone origin b) Zone III; quartz, orthoclase, plagioclase, biotite, muscovite, sillimanite, iron-ore, tourmaline and graphite (?) c) West of Sawando (沢渡) Nishiharuchika-mura (西湷近 村), Kamiina-gun

18: a) Mudstone, fine-grained b) Thermally metamorphosed slightly; muscovite and biotite c) West of Kamiarisu (上有住) station, Kamiarisu-mura, Kesen-gun (気仙郡)，Iwate Pref.

19: a) Mudstone, including grains of silty size b) Thermally metamorphosed (?) ; carbonate and muscovite c) West of Kamiarisu station, Kamiarisumura, Kesen-gun 
rock in most of chemical analyses by former authors. But this distinction is important in consideration on their chemical property, and therefore, so far as discrimination is possible, they are assigned as either mudstone or siltstone.

Of the seventeen clayslates (mudstones and siltstones) analysed by us, some are essentially non-metamorphosed, but others are more or less metamorphosed. In this report, the chemical compositions (except iron oxides and water) of clayslates within metamorphic Zone I and within the lower part of Zone II are regarded to be essentially the same as their original compositions.

\section{Mineral}

Mineral constituents are identified under microscope and by $\mathrm{X}$-ray powder method. Those of the non-metamorphosed mudstone and siltstone are quartz, plagioclase, microcline, illite, clastic muscovite, carbonaceous matter, chlorite, iron ores, clastic biotite and heavy minerals. Besides, carbonates and radiolarian remains (consisting of quartz and chlorite) are included though rarely. The above-mentioned order of arrangement approximately corresponds with the order of abundance. Volume of each mineral, however, is variable case by case. For example, clastic muscovite is often concentrated in some special thin layers or lamina; siliceous mudstone (cherty mudstone) is rich in cryptocrystalline quartz and illite but poor in feldspars and other minerals.

It is a notable fact that the clayslates treated by us are rich in feldspars.

\section{Chemical composition}

Results of chemical analyses of seventeen clayslates are shown in nos. $1 \sim 17$ in Table 1 .

Comparison with Clarke's and Eckel's average compositions of worlds' Paleozoic shale

New comprehensive average composition of Paleozic shales to take the place of the older averages by Clarke (1924, p. 552) and by Eckel (1908) is not given at present. And major elements of chemical compositions in various recent studies are not so different from them. So, our analyses is compared with both older averages.

For this purpose, their recalculated average compositions excluding water, carbon dioxide and others are shown in table 2.

(i) higher content of $\mathrm{SiO}_{2}$ : It is obvious from the table 2 that the present clayslate carries larger $\mathrm{SiO}_{2}$ content $(=66.44 \%)$ than 
Table 2. Recalculation of various averaged and composite analyses of clayslates, excluding water, carbon dioxide, carbon and other minor constituents.

\begin{tabular}{|c|c|c|c|c|c|c|c|c|c|}
\hline & 1 & 2 & 3 & 4 & 5 & 6 & 7 & 8 & 9 \\
\hline & \multicolumn{4}{|c|}{ Northern Kiso district } & 葛密 & 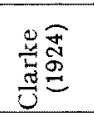 & 氖焉 & 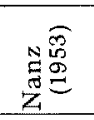 & 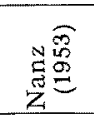 \\
\hline & $\frac{8}{3}$ & 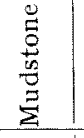 & 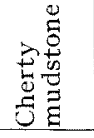 & 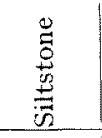 & 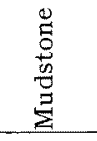 & $\frac{3}{\frac{0}{6}}$ & $\frac{\mathbb{9}}{\stackrel{0}{\pi}}$ & 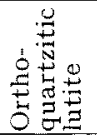 & 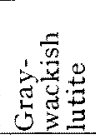 \\
\hline $\begin{array}{l}\mathrm{SiO}_{2} \\
\mathrm{TiO}_{2} \\
\mathrm{Al}_{2} \mathrm{O}_{3} \\
\mathrm{Fe}_{2} \mathrm{O}_{3} \\
\mathrm{FeO} \\
\mathrm{MnO} \\
\mathrm{MgO} \\
\mathrm{CaO} \\
\mathrm{Na}_{2} \mathrm{O} \\
\mathrm{K}_{2} \mathrm{O} \\
\mathrm{P}_{2} \mathrm{O}_{5} \\
\mathrm{FeS}_{2}\end{array}$ & \begin{tabular}{r|}
66.44 \\
0.74 \\
17.66 \\
2.28 \\
3.40 \\
0.06 \\
2.33 \\
0.67 \\
2.06 \\
4.18 \\
0.18
\end{tabular} & \begin{tabular}{r|}
65.14 \\
0.83 \\
18.77 \\
3.52 \\
2.75 \\
0.05 \\
2.35 \\
0.36 \\
1.85 \\
4.17 \\
0.21
\end{tabular} & $\begin{array}{r}71.50 \\
0.63 \\
14.61 \\
1.39 \\
3.57 \\
0.09 \\
2.36 \\
0.42 \\
1.51 \\
3.76 \\
0.16\end{array}$ & \begin{tabular}{r|}
70.68 \\
0.62 \\
14.90 \\
1.72 \\
2.87 \\
0.03 \\
1.93 \\
0.96 \\
2.95 \\
3.18 \\
0.16
\end{tabular} & $\begin{array}{r}64.13 \\
0.85 \\
18.52 \\
2.16 \\
4.73 \\
0.06 \\
3.09 \\
0.64 \\
3.09 \\
2.50 \\
0.23\end{array}$ & $\begin{array}{r}64.82 \\
0.82 \\
17.73 \\
4.35 \\
3.13 \\
\mathrm{~T} \\
2.50 \\
1.52 \\
1.09 \\
3.88 \\
0.16\end{array}$ & $\begin{array}{r}64.51 \\
0.78 \\
18.42 \\
2.39 \\
3.89 \\
\text { n. d. } \\
2.77 \\
1.64 \\
1.27 \\
3.93 \\
\text { n. d. } \\
0.4\end{array}$ & $\begin{array}{r}62.29 \\
0.53 \\
24.24 \\
4.43 \\
0.18 \\
\text { none } \\
0.42 \\
0.14 \\
0.20 \\
7.48 \\
0.09\end{array}$ & $\begin{array}{r}61.69 \\
0.98 \\
19.21 \\
1.25 \\
7.27 \\
0.05 \\
3.33 \\
0.71 \\
1.75 \\
3.59 \\
0.17\end{array}$ \\
\hline Total & 100.00 & 100.00 & 100.00 & 100.00 & 100.00 & 100.00 & 100.00 & 100.00 & 100.00 \\
\hline$\frac{\mathrm{Al}_{2} \mathrm{O}_{3}}{\mathrm{Na}_{2} \mathrm{O}}$ & 8.59 & 10.13 & 9.66 & 5.05 & 6.00 & 16.29 & 14.55 & 12.46 & 11.00 \\
\hline$\frac{\mathrm{Na}_{2} \mathrm{O}}{\mathrm{K}_{2} \mathrm{O}}$ & 0.49 & 044 & 0.40 & 0.93 & 1.24 & 0.28 & 0.32 & 0.26 & 0.49 \\
\hline
\end{tabular}

1: Average of 17 clayslates (mudstones, cherty mudstones and siltstones)

2: Average of 8 mudstones

3: Average of 2 cherty mudstones

4: Average of 2 siltstones

5: Average of 2 mudstones

6: Composite analysis of 51 Paleozoic shales

7: Average of 36 Paleozoic slates

8: Average of 2 Pre-Cambrina ortho-quartzitic lutites

9: Average of 2 Pre-Cambrina graywackish lutites

those of Eckel $(=45.51 \%)$ and Clarke $(=64.82 \%)$.

When we distinguish mudstone strictly from siltstone by means of grain size measurement in thin section, eight samples out of the analysed clayslates obviously belong to mudstone including silty mudstone. Their averaged $\mathrm{SiO}_{2}$ content is $65.14 \%$, and is slightly larger than Clarke's and Eckel's average. The average $\mathrm{SiO}_{2}$ content for siltstone $(=70.68 \%)$ is much larger. In the pelitic sediments of the Permian geosyncline, siltstone and silty 
mudstone are generally predominant over mudstone. Accordingly, this fact is apparently an important sedimentological framework of the high $\mathrm{SiO}_{2}$ content under question.

Another reason for the apparent high content of $\mathrm{SiO}_{2}$ is that the clayslates analysed include not only ordinary clayslate but also cherty clayslate. Some cherty clayslates can not be megascopically discriminated from ordinary clayslates, but its cherty nature is easily ascertained under microscope. Cherty slate is poor in clastic grains of quartz and feldspar, and relatively rich in illite, compared with chlorite, carbonaceous matter and iron ore, and moreover, any laminar texture is not found even under microscope.

(ii) higher content of $\mathrm{Na}_{2} \mathrm{O}$ and larger ratio of $\mathrm{Na}_{2} \mathrm{O} / \mathrm{K}_{2} \mathrm{O}$ : The present average composition shows higher content of $\mathrm{Na}_{2} \mathrm{O}$ and larger $\mathrm{Na}_{2} \mathrm{O} / \mathrm{K}_{2} \mathrm{O}$ ratio than Clarke's and Eckel's average.

Nearly all of $\mathrm{Na}_{2} \mathrm{O}$ content is to be present only in plagioclase grain. Accordingly, this deviation from the world's average implies that the present clayslates carry comparatively larger amount of fresh plagioclase grains. This fact is in accord with the existence of aboundant plagioclase grain in graywacke alternating with clayslate.

(iii) Lower content of $\mathrm{CaO}$ : The present average contains less $\mathrm{CaO}$ than that of Clarke and Eckel. This is due to the deficiency of carbonates in the matrix. This tendency is easily predicted from the principal lithological characteristics of the Paleozoics except Yabuhara formation that they are almost barren of carbonate sediments and basic volcanic rocks.

\section{Possible relation between $\mathrm{CaO}$ content and stratigraphical depth}

Haramura (1961) pointed out a remarkable tendency that the analysed clayslates from his "northwestern" part tend to be lower in $\mathrm{CaO}$ than those from his "southeastern" part. This relation is well shown in his $\mathrm{CaO}-\mathrm{Na}_{2} \mathrm{O}-\mathrm{K}_{2} \mathrm{O}$ triangular diagram. He considered such regional difference in chemical composition is not due to the metamorphism but to an inheritting nature from the difference in original comporition.

In the $\mathrm{CaO}-\mathrm{Na}_{2} \mathrm{O}-\mathrm{K}_{2} \mathrm{O}$ diagram (Fig. 3) chemical analyses of seventeen clayslates by ourselves, as well as fifteen analyses by Haramura (1961) and six by Oki (1960) are also replotted in the same diagram. Not only our analyses but also most of Haramura's and Oki's analyses can be assigned either to the Misogawa formation, or to the Yokokawa formation or to the Kuwazawa formations, as 


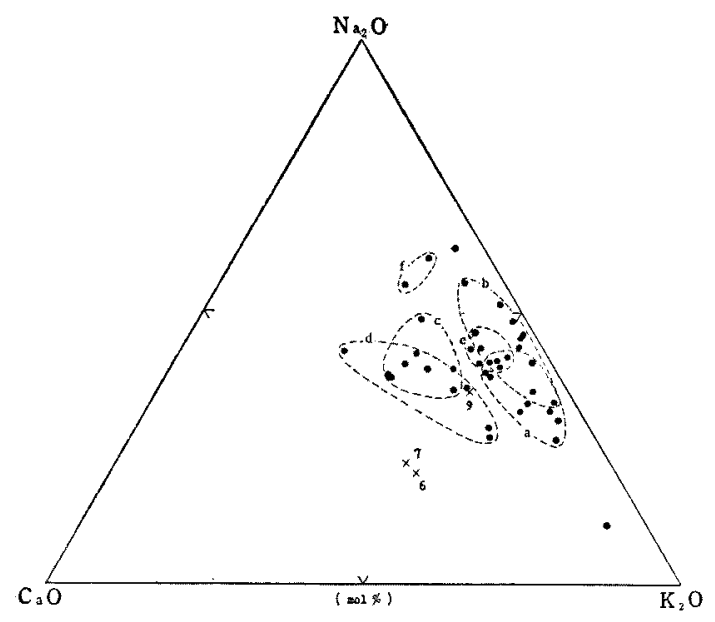

Fig. 3. $\mathrm{Na}_{2} \mathrm{O}-\mathrm{CaO}-\mathrm{K}_{2} \mathrm{O}$ diagram for claystates.

In addition to our data, Haramura's and Oki's data are also plotted. 40 clayslates are grouped into 6 groups, except 1 silltstone from Narai formation and 1 mudstone and 4 cherty mudstones from Yabuhara and Yokokawa formation
a : 8 analyses from Misogawa formation
$\mathrm{b}$ : 6 analyses from northern part of Yokokawa formation
c : $\mathbf{5}$ analyses from southern part of Yokokawa formation
d : 7 analyses from Kawazawa formation
e : 6 analyses from the eastern area from Tenryû River
$f: 2$ analyses from Toyoma formation
$6,7 \& 9$ : Analyses reported by Clarke, Eckel and Nanz shown in table 2

defined by our geological research. These clayslates are grouped into five groups in the diagram as follows: group a from the Misogawa formation; group $b$ from the northeastern part of the Yokokawa formation; group $c$ from the southwestern part of the Yokokawa formation; group $d$ from the Kuwazawa formation; and group $e$ from Haramura's "southeastern part" located to the east of the Tenryugawa (River). Most of the samples of group $e$ belong surely to the Kuwazawa formation. But it is uncertain whether the others belong to the Kuwazawa or Yokokawa formation. Therefore, the analyses from Haramura's "southeastern" part are grouped into a distinct group, for convenience.

Although more analyses are needed to ascertain geochemical characteristics, if any, of each Paleozoic formation, at least the 
following tendency is suggested at present; minor difference in chemical composition (especially ratio of $\mathrm{CaO}$ to alkalies) of slate is present among different formations. The field of each group in the diagram partially overlaps each other. It is, however, noteworthy that the field $d$ (Kuwazawa formation) is located nearer to $\mathrm{CaO}$ apex than the other fileds and overlaps only with the field $c$ (southeastern part of the Yokokawa formation). From geological viewpoint, the Kuwazawa formation occupies the highest horizone in the stratigraphic column of the Paleozoics. Consequently, it is possible that this chemical peculiarity of the Kuwazawa formation represents a change of sedimentological condition at the later stage of the geosynclinal evolution, because such specialized sedimentological features as frequent intercalation of intraformational conglomerate is actually recognized in the Kuwazawa formation.

It is strange, however, that the fields of group $c$ and $b$ are separated distinctly from each other, though the two belong to the same Yokokawa formation. The former is, together with group $d$ (Kuwazawa formation), located nearer the apex of $\mathrm{CaO}$. This phenomenon contradicts the above-mentioned interpretation. The difference in metamorphic grade is suggestive for this problem. Group $c$ possibly may represent the more metamorphosed part (highest-grade part of Zone I and Zone II) and the group $b$ the less metamorphosed rocks (Zone I). Therefore, there remains a possibility that larger content of $\mathrm{CaO}$ of the group $c$ and $d$ is to a certain degree, though not exclusively, an effect of local extent of the metamorphism.

\section{Variation of $\mathrm{Al}_{2} \mathrm{O}_{3} / \mathrm{Na}_{2} \mathrm{O}$ ratio in different formations}

$\mathrm{Al}_{2} \mathrm{O}_{3} / \mathrm{Na}_{2} \mathrm{O}$ ratio is generally considered as a good abbreviated chemical index of maturity for fine-grained sediments (Pettijohn 1957, p. 103 and p. 509). As was already described, clayslate from the Kiso district is as a rule rich in $\mathrm{Na}_{2} \mathrm{O}$, and its $\mathrm{Al}_{2} \mathrm{O}_{3} / \mathrm{Na}_{2} \mathrm{O}$ ratio is smaller than the world's average by Clarke and by Eckel. In this sense, the present clayslate is regarded as rather "immature".

$\mathrm{Al}_{2} \mathrm{O}_{3} / \mathrm{Na}_{2} \mathrm{O}$ ratio for the clayslate from northwestern area (stratigraphically from the Misogawa formation) is compared with that from the southeastern area (mostly from the Yokokawa and Kuwazawa formations). Average $\mathrm{Al}_{2} \mathrm{O}_{3} / \mathrm{Na}_{2} \mathrm{O}$ ratios are separately calculated for mudstone and siltstone, as shown in Table 3 . In the former area, the ratios for both mudstone and siltstone are larger than in the latter area. That is to say, the clayslates of the Misogawa 
Table 3. Average of $\mathrm{Al}_{2} \mathrm{O}_{3} / \mathrm{Na}_{2} \mathrm{O}$ ratio of mudstone and siltstone in the nothern Kiso district

\begin{tabular}{l|c|c}
\hline Rock types & Northwestern area $* 1$ & Southeastern area *2 \\
\hline Mudstone & 11.6 & 7.9 \\
& $(6) * 3$ & $(11)$ \\
\hline Siltstone & 8.5 & 6.7 \\
& $(3)$ & $(11)$
\end{tabular}

Cherty mudstones and clayslates of the highest metamorphic grade are excluded in this average.

In addition to chemical analyses by ourselves, ones by Haramura as well as by Oki are included. Concerning analyses by both authors, clayslates with less than $65 \% \mathrm{SiO}_{2}$ are regarded as mudstone, ones with $\mathrm{SiO}_{2}$ from $65 \%$ to 7096 as siltstone, and ones with more than $70 \% \mathrm{SiO}_{2}$ as cherty mudstone, respectively.

*1. Northwestern area means the area on the northwest side of the Yabuhara formation terrain and includs western half of Haramura's

"northwestern prat" (1961), Stratigraphically, except for one sample all the rocks analysed belong to the Misogawa formation.

*2. Southeastern area means the area on the southeast side of Yabuhara formation terrain. Eastern half of Haramura's "southeastern part" (1961) is included in this area. Except one sample from the Narai formation, all other rocks analysed from this area belong to the Yokokawa and Kuwazawa formations.

*3. Numerical within parenthesis indicates number of chemical analyses used for average.

formation distributed in the northeastern area are considered to be relatively less immature than those of the Yokokawa and Kuwazawa formations in the southwestern area. From the stratigraphical standpoint, the Misogawa formation is older than the Yokokawa and Kuwazawa formations. Therefore, it is possible that the probable change of sedimentological condition at the later stage (at the time of deposition of the Yokokawa and Kuwazawa formations) ofthe Permian geosyncline gave rise to "immaturity" of sediments.

But this problem is not so simple. The Misogawa formation is distributed only in the northwestern area. Its stratigraphical equivalent in the southeastern area has a different name of Narai formation after its own distinct lithology: the Misogawa formation bundantly contains massive graywacke, while the Narai formation consists mainly of clayslate and is poor in graywacke. The stratigraphically upper formations - the Yokokawa and Kuwazawa formations - are distributed exclusively in the southeastern area, resting conformably upon the Narai formation. Neither they nor their 
equivalents are seen in the northwestern area at all. Unde1 these circumstances, it is also possible that the above-mentioned difference of $\mathrm{Al}_{2} \mathrm{O}_{3} / \mathrm{Na}_{2} \mathrm{O}$ ratio between two areas is not related with difference in stratigraphic horizon but represents a regional difference in sedimentological condition to control clayslate property.

There are left alternatives in interpreting the regional divergency of $\mathrm{Al}_{2} \mathrm{O}_{3} / \mathrm{Na}_{2} \mathrm{O}$ ratio, and solution of this problem requires more chemical analyses of clayslates from the other formations.

Comparison with average compositions of Nanz's graywackisch and orthoquartzitic lutites

Nanz (1953) pointed out an obvious difference in chemical composition between Pre-Cambrian orthoquartzitic lutite and graywackish or eugeosynclinal lutite. According to him, the latter contains more of mobile elements $\left(\mathrm{CaO}, \mathrm{MgO}\right.$ and $\left.\mathrm{Na}_{2} \mathrm{O}\right)$ and less residual elements $\left(\mathrm{SiO}_{2}\right.$ and $\left.\mathrm{Al}_{2} \mathrm{O}_{3}\right)$.

When our average is compared with the averages for Nanz's two groups, it is readily recognized from a glance at the table 2 that the content of every component except $\mathrm{SiO}_{2}$ (and $\mathrm{Al}_{2} \mathrm{O}_{3}$ ) in the present clayslate is very similar to graywackish lutite out of Nanz's two kinds of lutite. Such similarity is dist nct in the contents of $\mathrm{Na}_{2}, \mathrm{O}$ $\mathrm{CaO}$ and $\mathrm{MgO}$. Moreover, the ratio of $\mathrm{Na}_{2} \mathrm{O} / \mathrm{K}_{2} \mathrm{O}$ is perfectly the same as in Nanz's graywackish lutite. In conclusion, the sedimentological fact that clayslate from the Kiso district belongs to geosynclinal sediments is confirmed also by its chemical composition.

Effects of regional metamorphism

Subtructive and additional change of chemical components during regionally metamorphic process is a very complicated subject. When chemical analyses of the clayslates from the present region are classified according to their metamorphic grade and their averages

Table 4. Iron oxides and water in each metamorphic zone

\begin{tabular}{c|c|c|c|c|c}
\hline & \multirow{2}{*}{$\begin{array}{c}\text { Number } \\
\text { of } \\
\text { Metamorphic zone }\end{array}$} & \multicolumn{4}{|c}{ Average } \\
\cline { 3 - 6 } & 6 & 5.63 & 0.61 & 3.91 & 1.06 \\
\hline Non-metamorphic zone & 6 & 5.29 & 0.41 & 2.70 & 0.33 \\
Zone I & 5 & 5.21 & 0.15 & 1.47 & 0.13 \\
Zone II & 4 & 5.58 & 0.16 & 1.57 & 0.15 \\
Zone III & 2 & & $\mathrm{Fe}_{2} \mathrm{O}_{3}+\mathrm{FeO}$ & $\mathrm{Fe}_{2} \mathrm{O}_{3}+\mathrm{FeO}$ & $\mathrm{H}+$ \\
\hline
\end{tabular}


are compared with each other, increase of dehydration as well as increase of the reduction of iron with rise of metamorphic grade can be clearly concluded from Table 4. In spite of almost constant content of total iron, ratio of ferric iron to total iron progressively decreases. The difference, however, is very slight between Zone II and III. Water progressively decreases as well, but this tendency is not found in transion from Zone II to III.

\section{Toyoma Clayslate in Kitakami Mountainland and Its Comparison with Mudstone from Kiso District}

The Toyoma formation is the uppermost of the Permian system distributed in the southern Kitakami mountainland. Its lithofacies is different from the Permian in the northern Kiso district, for it consists mainly of black mudstone called Toyoma clayslate, and contains neither chert nor basaltic rocks.

The chemical composition is given in nos. 18 and 19 in table 1 . The average chemical composition of the Toyoma clayslate can be compared with that of the mudstone in the Kiso district in table 2. The former is different from the latter in such components as $\mathrm{Na}_{2} \mathrm{O}$, $\mathrm{FeO}+\mathrm{Fe}_{2} \mathrm{O}_{3}$ and $\mathrm{MgO}$.

X-ray experiment indicates that the Toyoma clayslate is richer in chlorite than the mudstone from Kiso. Therefore, the larger contents of iron exides as well as $\mathrm{MgO}$ are in accord with the characteristics of mineral composition.

Content of $\mathrm{Na}_{2} \mathrm{O}$ in Toyoma clayslate amounts to $3.09 \%$ which is much larger than that of the mudstone from Kiso, while content of $\mathrm{K}_{2} \mathrm{O}$ is $2.50 \%$, which is much smaller than the mudstone from Kiso. $\mathrm{Al}_{2} \mathrm{O}_{3}$ content is essentially of the same order in both mudstone. Accordingly, $\mathrm{Al}_{2} \mathrm{O}_{3} / \mathrm{Na}_{2} \mathrm{O}$ ratio $(=6.00)$ of the Toyoma slate is much smaller, and $\mathrm{Na}_{2} \mathrm{O} / \mathrm{K}_{2} \mathrm{O}$ ratio $(=1.24)$ is much larger than the mudstone from Kiso of which the former is 10.13 and the latter is 0.44. It is especially noteworthy that $\mathrm{Na}_{2} \mathrm{O} / \mathrm{K}_{2} \mathrm{O}$ ratio $(=1.24)$ is larger than 1 , because clayslate in which $\mathrm{Na}_{2} \mathrm{O}$ exceeds $\mathrm{K}_{2} \mathrm{O}$ is very uncommon. In the sense that the Toyoma clayslate is rich in $\mathrm{Na}_{2} \mathrm{O}$ and poor in $\mathrm{K}_{2} \mathrm{O}$, it may be reasonable to consider the Toyoma clayslate to be a considerably "immature" mudstone.

\section{REFERENCES}

Clarke, F. W.(1924), Data of geochemistry. U.S. Geol. Survey Bull., 770.

Eckel, E.C. (1904), On the Chemical composition of American shales and 
roofing slates. Jour. Geol, 12, 25 29.

Haramura, H. (1961), Chemical composition of Paleozoic slates II. Tatuno-Sicziri district in Nagano Prefecture. Geol. Soc. Japan Jour., 67, 671 675 (in Japanese).

Isomi,H. and M.Katada (1959), Consideration on some sedimentary features of nonmetamorphosed Upper Paleozoics and Ryōke metamorphics in the northern part of Kiso mountainland, Central Japan. Geol. Surv. Japan Bull., 10, 1037 1052 (in Japanese).

Katada, M. and H. Isomi (1962), Ina quadrangle in the grological map of Japan (scale 1/50,000). Geol. Surv. Japan (in Japanese).

Miyashiro, A, and H. Haramura (1962), Chemical composition of Paleozoic slates IV. Zonal distribution of geosynclinal sediments and the position of regional metamorphic basalats. Geol. Soc. Japan Jour., $68,75 \sim 82$ (in Japanese).

Murayama, M. and M. Katada (1957), Akaho quadrangle in the geological map of Japan (scale 1/50,000). Geol. Surv. Japan (in Japanese).

Nanz, R.H., Jr. (1953), Chemical composition of Pre-Cambrian slates with notes on the geochemical evolution of lutites. Jour. Geol., 61, $51 \sim 64$.

Oki, Y. (1961), Metamorphism in the northern Kiso range, Nagano Prefecture, Japan. Japan. Jour. Geol. Geogr., 32, 479 496.

Pettijohn, F.J. (1957), Sedimentary rocks. Harpar \& Brothers, New York.

\section{北部木曾地方の古生層および北上山地登米層 \\ の粘板岩の化学成分}

$$
\begin{aligned}
& \text { 片田正人礒兒博 } \\
& \text { 大㷊えい山田貞子 }
\end{aligned}
$$

\section{摘 要}

長野県, 北部木曾地方の古生層の, 粘板岩（17コ）および北上山地上有住村で採集し た登米粘板岩（2コ）の化学分析值（主要 13 成分）を公表し，それらの特徴ならびに釷 物組織・地貿との関連性に関して $2 \cdot 3$ 付言した。

化学成分上の特徴を略記すると以下のようである。まず北部木㲘地方の粘板岩は， Clarke などによる世界各地の古生層粘板岩と比較すると, $\mathrm{SiO}_{2} \cdot \mathrm{Na}_{2} \mathrm{O}$ が多く $\left(\mathrm{Al}_{2} \mathrm{O}_{3} /\right.$ $\mathrm{Na}_{2} \mathrm{O}$ 比が小さく， $\mathrm{Na}_{2} \mathrm{O} / \mathrm{K}_{2} \mathrm{O}$ 比が大きい, $\mathrm{CaO}$ が少ない。また領家变成作用の影留 として，办の減少と，鉄の還元が認められる。

登米粘板岩は，上記地方の粘板岩に比較して， $\mathrm{Fe}_{2} \mathrm{O}_{3} \cdot \mathrm{FeO} \cdot \mathrm{MgO}$ および $\mathrm{Na}_{2} \mathrm{O}$ が多 wo 